ФОРМУВАННЯ ЦИРКУЛЯРНИХ МОДЕЛЕЙ СПОЖИВАННЯ: МЕХАНІЗМИ ДЕРЖАВНОГО РЕГУЛЮВАННЯ

\title{
DEVELOPMENT OF CIRCULAR CONSUMPTION PATTERNS: MECHANISMS OF STATE REGULATION
}

\begin{abstract}
y cmammi розроблено механізми державного регулювання процесів формування циркулярних моделей споживання. Виокремлено зміни, що сприяють розвитку економіки спільного споживання: технологічн зміни: поширення технологій четвертої промислової революції і розвиток глобальної мережі Інтернет трансформували ставлення споживачів до форм володіння продукцією, способів ії придбання і використання; економічні зміни: цифрровізація економіки, учинення транзакцій віртуально, поширення електронної комерції, з одного боку, і економічні кризи, зниження рівня зайнятості, а також купівельної спроможності - $з$ іншого, змінили ставлення до форм володіння продукцією і способів ї експлуатації; соціальні зміни: споживання як центральний проєкт у життя людини i розширення можливостей задоволення потреб із найменшими витратами при звели до значного зростання спільного споживання. Здійснено огляд систем циркуляції ресурсів і продуктів у рамках спільного використання. Показано, що натепер $€$ три системи циркуляції ресурсів і продуктів у рамках спільного використання: ринки обслуговування продукції, перерозподілу і спільний спосіб життя. Проаналізовано потенціал бізнес-моделі продукту як послуги. Зазначено, що в даній бізнес-моделі клієнти використовують продукти через оренду або оплату за використання, а не через стандартну покупку у власність. Ця модель приваблива для компаній, які мають високі експлуатаційні витрати і можливість керувати обслуговуванням продукту, а також повертати залишкову вартість у кінці життєвого циклу продукції завдяки повторному використанню у виробництві окремих елементів і деталей продукту. Однак для розвитку такої бізнес-моделі в життєвий цикл продукту вже повинні бути вбудовані замкнуті ланцюжки поставок технології, що дозволяють відновлювати продукцію в кінці їі використання.
\end{abstract}

Ключові слова: механізми державного регулювання, циркулярна модель споживання, бізнес-модель продукту, циркуляція ресурсів. The mechanisms of state regulation of the processes of formation of circular consumption patterns are developed in the article. The following changes that contribute to the development of the economy of joint consumption are highlighted: technological changes: the widespread use of technologies of the fourth industrial revolution and the development of the global Internet have transformed the attitude of consumers to the forms of ownership of products, the ways in which they are acquired and used; economic changes: digitalization of the economy, virtual transactions, widespread e-commerce on the one hand, and economic crises, reduced employment, as well as purchasing power - on the other hand, chang of the attitude to the form of ownership of products and the way they are operated; social changes: consumption as a central project in human life and increased capacity to meet needs at the lowest cost led to a significant increase in shared consumption. The system of circulation of resources and products within the framework of joint use is inspected. It is shown that today there are three systems for the circulation of resources and products in the framework of joint use: product service markets, redistribution and a general lifestyle. The potential of the business model of the product as a service is analyzed. It is indicated that in this business model, customers use products through rent or payment for use, and not through standard ownership purchase. This model is attractive for companies that have high operating costs and the ability to manage product maintenance, as well as return residual value at the end of the product life cycle using individual product elements and parts repeatedly in produc tion. However, to develop such a business model, closed supply chains and technologies that allow to restore products at the end of their use must already be built into the product life cycle.

Key words: mechanisms of state regulation, circular model of consumption, business model of product, circulation of resources.
Національний університет цивільного захисту України
Постановка проблеми в загальному вигляді. Стратегія виробництва продукту для тривалого використання з урахуванням максимізації сукупного екологічного, економічного та соціального ефекту для суспільства має на меті скорочення частоти заміщення і підвищення ефективності у споживанні ресурсів.

Однак, з одного боку, тривалий термін служби продукту призводить до зниження впливу на навколишнє середовище, тому що не вимагає виробництва нових товарів і використання для цього додаткових ресурсів. 3 іншого боку, якщо для використання продукту необхідні такі ресурси, як енергія, вода або паливо, необхідно оптимізувати його термін служби з урахуванням розроблення нових технологій ресурсо- й енергоефективності у процесі експлуатації.

Аналіз останніх досліджень і публікацій. Необхідно зазначити, що різнохарактерні підходи до державного регулювання циркулярної економіки висвітлені в наукових працях таких учених, як: С.О. Мащенко [1], І.Є. Міхно [2], Ю.В. Орловська [3], Н.В. Пахомова [4] та інші. Однак переважно вчені і практики розглядають окремі аспекти формування та впровадження принципів циркулярної економіки.

Виділення не вирішених раніше частин загальної проблеми. Беручи до уваги численні наукові напрацювання стосовно цир- 
кулярної економіки, варто зазначити, що в різнохарактерних наукових джерелах вони розглядаються окремо. Що стосується державного регулювання формування циркулярних моделей споживання, то дана проблема потребує поглибленого дослідження.

Мета статті - розроблення механізмів державного регулювання процесів формування циркулярних моделей споживання.

Досягнення поставленої мети передбачає вирішення низки специфічних завдань:

- виокремлення змін, що сприяють розвитку економіки спільного споживання;

- огляд систем циркуляції ресурсів і продуктів у рамках спільного використання;

- аналіз потенціалу бізнес-моделі продукту як послуги.

Виклад основного матеріалу. Традиційно існують дві стандартні моделі етапу споживання в циркулярній економіці: споживання і використання нового продукту, тобто первинне використання, для продовження терміну служби якого застосовуються технічне обслуговування і ремонт; вторинне використання продукту, що був у вживанні, яке доповнюється новими моделями: продукт як послуга, платформи спільного використання й обміну. Водночас у циркулярній економіці споживач прагне до тривалого терміну первинного використання, на відміну від стратегії запланованого старіння продукту для підтримки попиту, виробник використовує стратегію виробництва для тривалого використання, заміщає падіння попиту на нові товари зростанням попиту на технічне обслуговування і ремонт [1; 3].

Наприклад, автоматична кулькова ручка на стадії використання споживає мало енергії, тому продовження терміну служби продукту $є$ екологічно безпечним, оскільки воно дозволяє уникнути споживання додаткових ресурсів у процесі виробництва, з одного боку, і здійснювати генерацію відходів - з іншого. I навпаки, якщо автомобіль розрахований на 50 років корисного використання, а тенденції енергоефективності показують, що споживання енергії для стандартного автомобіля буде на 50\% нижче за 10 років, а також рівень вихлопів знижений на 20\%, то продовження терміну служби такого автомобіля втрачає сенс. Тому необхідно оцінити й оптимізувати загальний вплив на навколишнє середовище протягом усього життєвого циклу продукту, а також сконструювати продукт для можливостей ремануфактурінга і повторного використання його окремих вузлів і деталей, що принесе низку вигод на стадії використання продукту:

- зниження загальної вартості володіння для клієнта;
- скорочення загального впливу на навколишнє середовище завдяки зниженню споживання ресурсів і викидів;

- можливість пропозиції додаткових послуг, як-от обслуговування, модернізація і додаткові модулі [2; 4].

Продукт повинен мати такі характеристики, як: надійність, доступність, ремонтопридатність, висока якість, безпека, енерго- і ресурсоефективність. Для виробника продовження терміну служби продукту несе як нові можливості, так і загрози.

У разі дизайну, націленому на тривалий термін служби, зниження продажів нових продуктів компенсується наданням послуг технічного обслуговування і ремонту. Технічне обслуговування та ремонт - це найважливіша діяльність, що виконується на етапі використання життєвого циклу продукту, щоб продовжити його функціонування на потрібному рівні продуктивності. Пропозиції з технічного обслуговування можуть включати: ремонт, діагностику, технічну підтримку, надання аналогічного продукту під час ремонту виробу, очищення, заміну пошкоджених частин. Дослідження підтверджують, що протягом життєвого циклу продукту післяпродажне обслуговування і запасні частини можуть генерувати потрійний обсяг первісної вартості нового виробу, тому технічне обслуговування служить джерелом конкурентних переваг і нових можливостей для бізнесу. Однак у разі продовження терміну служби продукту технічне обслуговування і ремонт криють несуть низку можливостей і загроз для компанії [2; 3].

Крім стандартної покупки продуктів у власність і способів продовження терміну корисного використання продукції, у циркулярній економіці розвиваються нові бізнес-моделі, як-от платформи спільного використання, які створюються для використання продуктів і активів різними людьми або організаціями, що мають низьку частку володіння. Приклади платформ спільного використання $є$ в багатьох галузях. Розвиток спільного використання веде до значного скорочення виробництва, споживання й утворення відходів.

Згідно з дослідженнями, економіка спільного споживання стала активно розвиватися в результаті глибоких технологічних, економічних і соціальних змін:

- технологічні зміни: поширення технологій четвертої промислової революції і розвиток глобальної мережі Інтернет трансформували ставлення споживачів до форм володіння продукцією, способів її придбання і використання;

- економічні зміни: цифровізація економіки, учинення транзакцій віртуально, поши- 
рення електронної комерції, з одного боку, і економічні кризи, зниження рівня зайнятості, а також купівельної спроможності - $з$ іншого, змінили ставлення до форм володіння продукцією і способів її експлуатації;

- соціальні зміни: споживання як центральний проєкт у житті людини і розширення можливостей задоволення потреб із найменшими витратами призвели до значного зростання спільного споживання [1; 2].

Натепер наявні три системи циркуляції ресурсів і продуктів у рамках спільного використання: ринки обслуговування продукції, перерозподілу і спільний спосіб життя.

1. Системи обслуговування продуктів належать до комерційних систем взаємного доступу, дозволяють споживачам здійснювати монетизацію обміну через базу для тимчасового доступу до товарів. Товари, що перебувають у приватній власності, можуть ділитися або здаватися в оренду через спеціальні торгові майданчики.

2. Ринки перерозподілу - це система спільного споживання, заснована на використанні товарів, що були у вживанні, і передачі їх від тих, кому продукти вже більше не потрібні. На деяких торгових майданчиках товари можуть бути безкоштовними. В інших випадках товари продаються, наприклад, на еВау, Craigslist тощо.

3. Спільний спосіб життя - система, заснована на споживанні і використанні продуктів людьми з однаковими потребами, які об'єднуються разом для обміну матеріальними і нематеріальними активами. Наприклад, споживачі спільно ухвалюють рішення про покупку продукту з урахуванням не тільки його ціни, а й вартості експлуатації. Наприклад, для допомоги покупцям у розрахунку загальної вартості володіння Міністерство навколишнього середовища і продовольства Данії розробило низку практичних інструментів та інструктивних матеріалів, які можуть бути використані під час закупівлі різних продуктів, що приведе до створення більш ресурсоефективних продуктів і економії коштів у довгостроковій перспективі [3; 4].

Дослідження показують, що економіка спільного використання має потенціал в області позитивних екологічних і економічних ефектів. Тому компанії повинні управляти цією новою моделлю споживання, щоб адаптувати поточні та майбутні бізнес-моделі для забезпечення нових джерел доходів. Виділяються такі способи управління спільним споживанням компаніями: продаж продуктів як послуг, прийом продукції від споживача в кінці їх використання, надання послуг із ремонту і техніч- ного обслуговування, створення нових ринків для спільного споживання.

Із платформами спільного використання тісно взаємопов'язана і володіє потенціалом для розвитку бізнес-модель продукту як послуги. У даній бізнес-моделі клієнти використовують продукти через оренду або оплату за використання, а не через стандартну покупку у власність. Ця модель приваблива для компаній, які мають високі експлуатаційні витрати і можливість керувати обслуговуванням продукту, а також повертати залишкову вартість у кінці життєвого циклу продукції за допомогою повторного використання у виробництві окремих елементів і деталей продукту. Однак для розвитку такої бізнес-моделі в життєвий цикл продукту вже повинні бути вбудовані замкнуті ланцюжки поставок і технології, що дозволяють відновлювати продукцію в кінці її використання. У продуктах як послугах постачальники товарів охоплюють ідею самих себе як постачальників послуг. Іноді це приводить не тільки до ефективного хеджування від волатильності витрат, але і до більш тісних взаємин із клієнтами і зростання продажів. Так, клієнт може орендувати автомобіль на три роки й обміняти його на більш енергоефективну модель. 3 урахуванням того, що компанія займається збором і ремануфактурінгом старих авто, така бізнес-модель приводить до створення замкнутих ланцюгів поставок, а також забезпечує більш глибокі взаємини із клієнтами. Загалом, дана бізнес-модель дозволяє компанії зберегти власність на продукт (отже, також ресурс), зберегти продукт у циклі для повторного використання, повторного виготовлення і продовження терміну його служби.

Висновки. Отже, у результаті дослідження можна дійти таких висновків:

1. Виокремлено зміни, що сприяють розвитку економіки спільного споживання: технологічні зміни: поширення технологій четвертої промислової революції і розвиток глобальної мережі Інтернет трансформували ставлення споживачів до форм володіння продукцією, способів ії̈ придбання і використання; економічні зміни: цифровізація економіки, учинення транзакцій віртуально, поширення електронної комерції, з одного боку, і економічні кризи, зниження рівня зайнятості, а також купівельної спроможності - $з$ іншого, змінили ставлення до форм володіння продукцією і способів її експлуатації; соціальні зміни: споживання як центральний проєкт у житті людини і розширення можливостей задоволення потреб із найменшими витратами привели до значного зростання спільного споживання. 


\section{ПУБЛІЧНЕ УПРАВЛІННЯ І АДМІНІСТРУВАННЯ В УКРАЇНІ}

2. Здійснено огляд систем циркуляції ресурсів і продуктів у рамкахспільного використання. Показано, що натепер є три системи циркуляції ресурсів і продуктів у рамках спільного використання: ринки обслуговування продукції, перерозподілу і спільний спосіб життя.

3. Проаналізовано потенціал бізнес-моделі продукту як послуги. Зазначено, що в даній бізнес-моделі клієнти використовують продукти через оренду або оплату за використання, а не через стандартну покупку у власність. Ця модель приваблива для компаній, які мають високі експлуатаційні витрати і можливість керувати обслуговуванням продукту, а також повертати залишкову вартість у кінці життєвого циклу продукції завдяки пвторному використанню у виробництві окремих елементів і деталей продукту.

\section{ЛIТЕРАТУРА:}

1. Мащенко С.О., Вовк М.С., Алієв Р.А. Теорія та методологія «зеленого будівництва». Економічний простір : збірник наукових праць. 2016. № 113. C. 220-230.

2. Міхно І.С. Методи утилізації відходів. Світовий досвід. Економіка, фрінанси, менеджмент : актуальні питання науки і практики. 2015. № 2. С. 68-78.

3. Орловська Ю.В., Яковишина Т.Ф., Орловський $€ . С$. Зелене будівництво як складова політики ЄС щодо розвитку циркулярної економіки. Східна Європа : економіка, бізнес та управління. 2016. № 5 (05). С. 365-371.

4. Пахомова Н.В., Рихтер К.К., Ветрова М.А. Переход к циркулярной экономике и замкнутым цепям поставок как фактор устойчивого развития. Вестник Санкт-Петербургского государственного университета. Серия «Экономика». 2017. Т. 33. Вып. 2. С. 244-268. 